\title{
Shelley traductor: magia, prodigio y conocimiento
}

\author{
VICENTE LÓPEZ FOLGADO \\ Universidad de Córdoba
}

\begin{abstract}
Resumen: Este trabajo se propone evaluar el trabajo de Shelley en traducción. En especial se centra sobre zonas de luz y sombra en las traducción que Shelley hace del auto de Calderón, obra que parece haberle obsesionado y servido de acicate para su imaginación romántica. En mi opinión, existe un hilo mítico y sutil que recorre la obra traductora de Shelley, desde la obra clásica de Eurípides, Los Cíclopes, hasta el Fausto de Goethe y el auto de Calderón, El mágico prodigioso. Parece que las tres obras reflejan algunas de sus preocupaciones literarias y psíquicas más importantes. Coincido con algunos críticos en que Shelley sentía la necesidad de traducir como terapia necesaria para estimular su inspiración poética.
\end{abstract}

Abstract: It is my aim here to assess the role of Shelley as a translator. I focus especially on some light and shady areas in Shelley's translation of a Calderón's auto, which seemed to have haunted his mind and stirred his romantic inspiration. I assume that there is a subtle, mythical thread that led Shelley's translation work from the classical play, Euripides' the Cyclops, through to Goethe's Faust and Calderón's auto, El mágico prodigioso. All the three seem to reflect some of his most relevant literary and psychic preoccupations. I share the view, expressed by some of his critics, that Shelley needed translation as a kind of exercise that was in fact a helping search for poetical inspiration.

Palabras Clave: Traducción interpretativa. Mitología. Teatro.

Key words: Interpretive translation. Mithology. Drama.

\section{Shelley: el traductor como camaleón}

Shelley fue un traductor prolífico, y aplicó sus excepcionales dotes a obras de numerosos autores en latín, griego, francés, alemán, italiano y español. Incluso tradujo parte de su obra al italiano. Por sus abundantes cartas, que revelan muchos datos y detalles psicológicos de su vida, sabemos que practicaba el ejercicio de la traducción con frecuencia. Según él mismo lo hacía por necesidad personal, porque le ayudaba, de manera propedéutica, a encender la mecha ('ignited the creative process' son sus elocuentes palabras) de la inspiración poética. Pocos románticos recurrieron a ese método de llamar a las musas, pero en Shelley la importancia del ejercicio traductor reside en que sus obras originales 
se ven matizadas y teñidas de las obras que traducía. Para él tal práctica ni era algo negativo, como se sostenía con frecuencia entonces, ni tan falsamente mimético. Según él mismo, ${ }^{1}$

As to imitation, poetry is a mimetic art. It creates, but it creates by combination and representation...one great poet is a masterpiece of nature which another not only ought to study but must study. $\mathrm{He}$ might as wisely and as easily determine that his mind should no longer be the mirror of all that is lovely in the visible universe, as exclude from his contemplation the beautiful which exists in the writings of a great contemporary.

Tal condición camaleónica del escritor es también piedra angular en el pensamiento del poeta John Keats, ya que para él el poeta no es nadie por sí mismo si no toma el tono y color de los rasgos e ideas de quienes le rodean. Para Shelley, menos radical en su planteamiento platónico, es el traductor quien mejor asume el papel de camaleón, haciendo que muchas de las ideas del escritor original transpase $\mathrm{y}$, de manera casi imperceptible, cale hasta su propia conciencia. El traducir la obra de otros, el buscar la expresión adecuada para expresar la idea clara y distinta, trouver le mot juste -según reza la expresión francesa- que se adecúe a los recursos de la propia lengua, requiere un enorme esfuerzo mental, que Shelley, experimentado traductor, equiparaba a la creación misma. Para Shelley los autores clásicos y el mundo griego era el primer incentivo creativo. Lo había aprendido de su amigo Thomas Love Peacock, un gran especialista y fiel enamorado de la literatura helénica ${ }^{2}$, cuyo profundo conocimiento de la misma fue decisiva para el estro romántico de Shelley. Pero hay en su biografía datos aún oscuros ${ }^{3}$, como la razón por la que se decidió por traducir The Cyclops entre tantas otras más atractivas para su personalidad. Y además, si había leido tan extensamente a Eurípides, ¿por qué de las diecinueve obras del griego, escogió ésa, la única de carácter satírico? Si tanto le atraían los cíclopes, ¿por qué no la versión de Homero en la Odisea? El monstruo rechazado por la sociedad, la comprensión por el aherrojado y marginado outcast era lo que había llevado a también a Mary Shelley a escribir Frankenstein, cuyo subtítulo es "The modern Prometheus", un trasunto del monstruo Polifemo clásico. En su Prefacio a la obra romántica leemos:

\footnotetext{
' P.B. Shelley, The Complete Poetical Works of Percy Bysshe Shelley, ed. Thomas Hutchinson, London: O.U.P., (1904), reset ed., 1943, 1986.

${ }^{2}$ T.J. Hogg, Memoirs of Shelley by Th. L. Peacock, ed. Humbert Wolfe, Dent, 2 vols., 1933. Ver también J.A. Notopoulos: The Platonism of Shelley. Duke Univ Press, Durham, NC, 1949.

${ }^{3}$ T.J. Hogg, The Life of P. B. Shelley, ed. Humbert Wolfe, 2 vols., Dent, 1933. Hogg dice que "He was never weary of studying the most perfect compositions of the Attic tragedians" (vol I, p. 138).
} 
Treat a person ill, and he will become wicked. Requite affection with scorn; - -let one being be selected, for whatevere reason, as a refuse of this kind-divide him, a social being from society, and you impose upon him the irresistible obligations-malevolence and selfishness.

No hay duda de que a Shelley le atraía la figura de los cíclopes, y en particular, el Polifemo de los Idilia de Teócrito, tal vez inducido por su amigo Leigh Hunt. Este clima psicológico gravitaba sobre la época y estaba fomentado por la novela gótica, y propiciado por el gusto por lo macabro, truculento y lo deforme. El gigante de Homero quizá era demasiado monstruoso, sanguinario y poco humano; el de Teócrito era un tanto grotesco e incluso cómico y patético; el de Eurípides estaba más dignificado, pues era rebelde y orgulloso ante los dioses. De alguna forma encarnaba su héroe predilecto, una proyección de su ego rebelde, el de artista rechazado o marginado por la sociedad, pero, no obstante, luchador noble y arrojado. El manido mito romántico del artista, en suma.

Leigh Hunt había escrito un ensayo por entonces en el que afirmaba que la mitología de Grecia y Roma no representaba tan sólo una colección de historias maravillosas, sino una serie de mitos teosóficos en los que ellos creian:

Every forest, to the mind's eye of a Greek, was haunted with superior intelligence. Every stream had it's presiding nymph, who was thanked for the draught of water...Y citando a Wordsworth: "The world is too much with us, Proteus rising from the sea / Or hear old Triton blow his wreathed horn". ${ }^{4}$

P. B. Shelley, parece claro, compartía esa actitud creyente, como la había compartido Wordsworth ${ }^{5}$, quien ejercía sobre él la atracción de un imán y daba sentido a su búsqueda de creencias que iban más allá de una fe cristiana a la que había renunciado desde sus años adolescentes en Eton. Toda su personalidad, tan proclive a aceptar ese plano o sustrato idealista, se ve impregnada de ese espíritu y ambiente mitologista en que lo sobrenatural convivía muy cercano a lo real. El traductor actúa, entonces, como un auténtico camaleón que se camufla con la tonalidad del entorno, porque es un ser que se identifica con el autor y comparte el mismo habitat ambiental, haciendo una trasmutación psíquica natural. Ello explica algunos hechos: en primer lugar, el que haya cometido algunos errores, debidos, sin duda, al insuficiente conocimiento filológico que poseía del griego

\footnotetext{
${ }^{4}$ L. Hunt, "Spirit of the Ancient Mythology". The Indicaror, 19 Jan. 1820, p. 115. Es uno de los muchos artículos y reseñas de obras que Hunt publicaba en revistas y periódicos.

5 D. Perkins, The Quest for Permanence: The Symbolism of Wordsworth. Shelley and Keats. Cambridge: Harvard U. Press, 1959.
} 
clásico, a pesar de sus intensos esfuerzos por dominarlo. ${ }^{6}$ En opinión de Arnott, la actitud de Shelley queda clara y manifiesta, y hasta cierto punto traicionada, por su propia traducción:

Shelley, though drawing much of his inspiration from classical standards and ideals, saw the Greek world through rose-coloured glasses. His conception of the Golden Age of Greece as pastoral, pure and picturesque is as valid as a reconstruction of eighteenth-century France entirely in terms of Le Petit Trianon. In this version Euripides' full-bloodedness, his frank brutality, are watered down with the stock Romantic vocabulary.

Por otra parte, lo que viene a perpetrar tal traición no es sino su fiebre clasicista, que recrea y actualiza una lectura mitológica hecha a su propia medida personal. Según el propio Arnott, la conversión en 'grotto' o 'pavillion' de la caverna batida por las olas de los cíclopes, y la de bosques peligrosos en cultivados jardines, tienden a evocar asociaciones más líricas, amables y dominadas. La traducción más actual de $\mathrm{Way}^{7}$, en comparación, refleja mejor el espíritu del original, a pesar de sus dudosas adaptaciones culturales para el 'coro' dramático. No obstante, creo que se ha subestimado a menudo la visión ingenua e idealista de Shelley. Su preocupación por Grecia, su más importante leitmotiv para su inspiración poética, entraña también un vivo interés por el convulso momento político por el que atravesaba ese país. Así lo prueban algunos de sus poemas dedicados a Grecia, como Hellas, de 1822. En las notas del Poema ${ }^{8}$, escritas por Mrs. Shelley leemos:

Shelley had hymned the dawn of liberty in Spain and Naples, in two odes dictated by the warmest enthusiam; he felt himself naturally impelled to decorate with poetry the uprise of the descendants of that people whose works he regarded with deep admiration, and to adopt the vaticinatory character in prophesying their success. Hellas was written in a moment of enthusiam.

En algunas de sus cartas Shelley hace alusión a esa misma fiebre mitologista que le indujo a empaparse de lecturas clásicas y, en última instancia, le llevó a tomar la decisión de dejar la Inglaterra mercantilista y anti-intelectual ('philistine'

\footnotetext{
"P.D. Arnott, An Introduction to the Greek Theatre, London \& New York: MacMillan, 1965. El capitulo X se titula "Problems of Translation" donde se habla, entre otras de la traducción de Shelley.

${ }^{7}$ A.S. Way, The Cyclops by Euripides, London: Loeb Series, 1912.

${ }^{8}$ P.B. Shelley, Shelley. Poetical Works. Ed. Th. Hutchinson, London: Oxford U. Press, 1970.
} 
en palabras de M. Arnold) por la Italia y el Mediterráneo cultural y espiritual. Escribe Shelley en el Prefacio del poema Hellas ${ }^{9}$ :

We are all Greeks. Our laws, our literature, our religion, our arts have their root in Greece...This is the age of the war of the oppressed against the oppressors, and every one of those ringleaders of the privileged gangs of murderers and swindlers, called Sovereigns, look at each other for aid against the common enemy, and suspend their mutual jealousies in the presence of a mightier fear.

\section{La traducción del Faust}

Un mito romántico que alimentó la feraz imaginación shelleyiana fue el Faust de Goethe, a pesar de lo escasamente conocido que era el propio Goethe entonces en Inglaterra, y a pesar del escaso conocimiento que Shelley parecía tener de la lengua alemana, según los datos biográficos de T. J. Hogg ${ }^{10}$. En una carta a su amigo J. Gisbourne escribe Shelley al respecto:

Have you read Calderón's Magico Prodigioso? I find a striking
similarity between Faust and this drama, if I were to acknowledge
Coleridge's distinction I should say, Göthe was the greatest
philosopher \& Calderón the greatest poet. Cypriano evidently
furnished the germ of Faust, as Faust furnished the germ of other
poems; although it is a different from it in structure and plan, as the
acorn from the oak.- - I have, -imagine my presumption- translated
several scenes from both, as a basis of a paper for our journal.

Ningún otro mito parece más cercano al propio Shelley que éste del Fausto, como lo era también para el mefistofélico Byron, con quien tuvo alguna discusión, según parece, en torno a este tema. En Calderón es el propio 'Demonio' quien aborda a Cipriano con la "ignorancia de la mala elección", distrayendo así su atención de su búsqueda de la verdad, como explica Parker ${ }^{12}$.

"The Complete Poems of Percy B. Shelley, with notes by Mary Shelley, New York: Modern Library Edition, 1994, p. 502.

16 T.J. Hogg, The Life of Percy Byshee Shelley, ed. Humbert Wolfe, 2 vols, Dent, 1933. Parece que Hogg juzgó a Shelley con demasiada severidad sobre este particular, en parte por polémicas con él. Lo que si consigna Hogg es el aprecio del poeta por Werther. Shelley tradujo parte del Prólogo y escenas de la I parte del Fatst animado por las alusiones y traducciones leidas por alguien de su circulo en Italia y Oxford, J. Gisbome (Lefters, ii, 301-8). Parece que fucron las ilustraciones de Retzsch, más que la primera versión, un tanto podada, al inglés de 1820 en si, las que le causaron una honda impresión. (Letters, ii, 407).

"Letlers, ii. 406-7.

12 A.A. Parker, The Theology of the Devil in the Drama of Calderon. London. 1958. La tentación se lleva a cabo primero por medio de la razón, y el "libre albedrio", pero si falla la prueba, entonces la pasión es la siguiente trampa. 
Pero Shelley buscó no un Fausto racionalista y amante del saber y el conocer que proporcionan las denominadas ciencias naturales -enmarcados en un contexto teológico, tal como Goethe queria ${ }^{13}$ - sino, más bien, un Fausto a su medida, entendido en clave política y rebelde para su inspiración romántica. La lectura, de acuerdo con el momento político en Italia y Grecia, es la de las luchas entre el tirano y los revolucionarios nacionalistas. Ello explica, sin duda, las diversas adiciones y amplificaciones del texto goethiano por parte del poeta inglés, ya que sus frecuentes cambios de sentido son debidos, no tanto al manifiesto escaso dominio que tiene del alemán, -y algo de eso hay también, sin duda, -cuanto al particular sesgo que da a la lectura de la obra. Shelley, fascinado como estaba por los fenómenos naturales -el viento, las nubes, el volcán y el agua sobre todocrea una serie de expresiones románticas propias, que utiliza en sus obras originales. El poder y fuerza del viento es una obsesión de su admiración por la naturaleza 'salvaje' (wilderness es el término recurrente). Es muy probable, aunque no demostrada, la deuda de Shelley con la figura de Satan de Lord Byron en su The Vision of Judgement ${ }^{1+}$, que, como la traducción de Shelley, tenía como destino la revista The Liberal. El personaje de Byron es un hombre refinado, de su época, un 'gentleman' adornado con esa cualidad tan inglesa de la dignidad social, basada en el orgullo de clase y el respecto de 'los iguales', con raices en una moral de conducta pública.

He turn'd as to an equal, not too low,

But kindly; Satan met his ancient friend

With more hauteur, as might an old Castilian

Poor noble meet a mushroom rich civilian.

(stanza xxxvi)

También es muy probable, sin embargo, que Shelley tuviera presente la figura de Mefistófeles del Dr Faustus de Marlowe ${ }^{15}$, que se presenta como un personaje hecho a la medida humana, con rasgos de persona real, casi familiar y, por supuesto, menos medieval, prototípico y distante que el de Goethe. Por eso se

\footnotetext{
${ }^{13}$ Dice Faust en el monólogo primero "Nacht" (versos 450 y ss.): Wo faß' ich dich, unendliche Natur?/ Euch Brïste, wo? Ihr Quellen alles Lebens/An denen Himmel und Erde hängt./ Dahin die welke Brust sich drängt - Versos que podemos traducir asi: ¿Dónde captarte, oh Natura infinita?' Tus pechos, dónde? tus manantiales de toda vidal de los que el cielo y la tierra dependen'A dónde se precipita el pecho marchito?

${ }^{i t}$ Este largo poema, publicado bajo el pseudónimo de 'Quevedo Redivivus', contiene una famosa cita 'exergo' muy apropiada para el tema tratado, de A. Pope: "That fools rush in where angels fear to tread".

${ }^{15}$ P.M. Palmer \& R.P. More, The Sources of the Faust Tradition from Simon Magus to Lessing, Oxford: Oxford U. Press, 1936.
} 
trata de una obra que es en parte "morality play" y en parte "heroic play", como bien observa Brockbank ${ }^{16}$. Afirma este crítico:

Dr Faustus, in relation to these plays ${ }^{17}$, might be called both a medieval and a Renaissance Morality; but it challenges and displaces the simple oppositions of earlier plays: 'subtle' science and 'studious desire' becomes the begetters of 'sensual appetite' and the devil is credited with an impressive 'knowledge of God's verity'. Yet it retains the great rival simplicities.

Si en el renacentista Marlowe su Dr Faustus nos recuerda al mito de Ícaro con sus 'waxen wings', arriesgando con osadía volar 'en precario' hacia regiones más altas de lo permitido al género humano, en Shelley Faust adquiere rasgos incluso de 'noble gentleman', no sólo en las preocupaciones morales, sino, sobre todo, en el afán de saber, el deseo de conocimiento y el placer de experimentar el conocimiento sensual del mundo. Placer, por otra parte, que se halla muy cercano al experimentado por los científicos naturalistas, cuya fama de hechiceros, magos, brujos o taumaturgos les causaron no pocos problemas sociales ${ }^{18}$.

En ambos es el poder y el conocimiento, prohibido o no por la moral, como en el caso del auto de Calderón, en que sólo es Dios el mágico prodigioso, lo que constituye el pretencioso acto de 'hybris' desafiante del poder divino. En el Dr Faustus ${ }^{19}$ leemos:

Cornelius: The miracles that magic will perform

Will make thee vow to study nothing else.

He that is grounded in astrology,

Enrich'd with tongues, well seen in minerals,

Had all the principles magic doth require;(....)

Dr Faustus: (....)Come, show me some demonstrations magical

That I may conjure in some lusty grove

And have these joys in full possession

\footnotetext{
${ }^{16}$ J.P. Brockbank, Marlow: Dr Faustus, London: Edward Arnold, 1962.

${ }^{17}$ La comparación se hace con una plétora de obras dentro de esta tradición renacentista y, de alguna forma, semejantes planteamientos, entre las que sobresalen la calvinista The Conflict of Conscience de N. Woods, The Temptation of Our Lord de Bishop Bale, Wyt and Science de J. Redford.

${ }^{18}$ No tenemos sino que hacer memoria y considerar casos como los de Roger Bacon (citado por Marlow en su Dr Faustus) en Inglaterra o B. Arias Montano en España.

${ }^{11}$ Cito por la edición de Longman Study Texts, ed. by L. Cookson (introduction by J. Kott, London, 1984, Act I, scene 1, p. I5.
} 
Las alteraciones, adiciones, reinterpretaciones y sesgos en la lectura que hace Shelley están realizados de forma calculada en su mayor parte. Su enfrentamiento al texto original fue un proceso de laboriosa tarea. Partiendo de una traducción literal en prosa, ofrecía luego otra versión en verso medido y rimado, en busca del efecto poético. Sortear los inesperados escollos de las palabras alemanas compuestas y de sílabas largas, y solventar los problemás semánticos así como las connotaciones de las palabras, es un ingente empeño que Shelley se echó sobre sus espaldas. $\mathrm{Y}$ puesto que ofrece ambas versiones, los cambios y adiciones pueden atribuirse a una elección realizada conscientemente. T. Webb coincide con esta opinión y cita un pasaje de una obra teórica de Shelley, Defense of Poetry, en la que habla de la ardua tarea de traducir poesía ${ }^{20}$.

En palabras de Shelley ${ }^{21}$, bellamente expresadas de forma idealista, el poeta acude en ayuda de un principio platónico de que la palabra, como un todo autónomo, no se puede desmenuzar en partes, pues sus componentes no dan la idea del conjunto:

...Hence the vanity of translation; it were as wise to cast a violet into a crucible that you might discover the formal principle of its colour and odour, as to seek to transfuse from one language into another the creations of a poet. The plant must spring again from its seed, or it will bear no flower-and this is the burthen of the curse of Babel.

Shelley expresó en varias otras ocasiones su idea de la traducción de poesía. Tal vez la más importante es aquella en la que hace hincapié en la condición de poeta que tiene el traductor: "There is no greater mistake than to suppose.....that the knowledge of a language is all that is required in a translator. He must be a poet, and as great a one as his original, in order to do justice to him"..2

\section{La traducción del auto El mágico prodigioso}

Aparte de dos estrofas de la obra calderoniana Cisma de Inglaterra, en las que se expone elaborados símiles y metáforas sobre las acciones de the bee, the rose y the taper, Shelley se interesó, sobre todo, por la obra de Calderón, $E l$ mágico prodigioso. Para ello estudió y recibió alguna lección de español, como las había recibido antes de italiano, por parte de sus amigos los Gisbourne, sobre todo de Mrs Gisbourne. ${ }^{23}$ Llega incluso a comparar al dramaturgo español con el propio Shakespeare:

\footnotetext{
20) Timothy Webb, The Violet in the Crucible, Oxford: Oxford U. Press, 1976.

21 P.B. Shelley, Defence of Poetry, ed. H.F. Brett-Smith, repr., Oxford U. Press, 1953, p. 29.

22. Thomas Medwin, The Life of Percy Bysshe Shelley, ed. Th. Hutchinson, repr. Oxford U. Press 1943.

${ }^{23}$ Dice en Letters, ii, 105: "We hve a house very near the Gisbournes, and it is from Mrs Gisbourne that I learnt Spanish enough to read these plays".
} 
I have been reading Calderon in Spanish-a kind of Shakespeare is this Calderon, \& I have some thoughts, if $\mathrm{i}$ find that I cannot do anything better, of translating some of his plays-and some greek ones besides-but my head is full of all sorts of plans. (Letters, ii, $115)$

No obstante, llegó sino a traducir fragmentos, como lo había hecho del griego, ya que su idea no era publicarlas, sino ejercitar su habilidad poética creadora. Así pues, quedan las tres escenas iniciales de la obra de Calderón, que realizó a principios de 1822. Curiosamente, en una carta de 1820 había comunicado su intención de invitar a Italia al poeta Keats para ayudarle a recuperar su salud física y mental y además queria enseñarle griego y español: "I intend to be the physician both of his body \& his soul, to keep the one warm \& to teach (the) other Greek and Spanish" (Letters, ii, 240).

Poco después sigue obsesionado con el mismo tema en otra carta: "I have been reading nothing but Greek and Spanish. Plato and Calderon have been my gods" (Letters, ii, 245) Y casi un mes más tarde ya había leido todos los autos con insistente y constante dedicación: "I am bathing myself in the light \& odour of the flowery \& starry Auto. I have read them all more than once" (Letters, ii, 250). Parece ser que, aunque anunció el final de su traducción de la obra (que él titula "Cyprian", por el principal protagonista), en realidad sólo escribió tres escenas de la Primera Jornada.

La obra de Calderón significó para Shelley el caldo de cultivo necesario para la germinación de la obra suprema de Goethe, su admirado Fantst. Algunos antecedentes ya han sido mencionados arriba, pero tal vez había que insistir en la pervivencia del tema a lo largo de los siglos y las diferentes culturas ${ }^{24}$.

Un personaje dramático esencial es Daemon, el demonio de Calderón, que actúa a la manera de Mefistófeles en Faust, en realidad un alter ego, bien antagonista dialéctico o subconsciente espiritual, necesario para el teatro como aunténtico personaje. Dice al efecto A. A. Parker ${ }^{25}$, vinculando el concepto de evil con su personificación ó devil, lo siguiente:

...it is essential for the full appreciation of Calderón's dramatisation of the idea of the (d)evil to realise that though as regards the stage plot he

\footnotetext{
${ }^{24}$ Gil de Santarém, fraile superior de los Dominico muerto en 1265 , de familia portuguesa, traductor del árabe de temas filosóficos y médicos, fue objeto de una leyenda dos siglos más tarde y tenido por nigromante. Su leyenda parece haber influido en Calderón para escribir su obra. Cf. I. McCleery, "Saintly physician, diabolical doctor, medieval saint" en Actas de la Society for Spanish and Portuguese Historical Studies, 2003.

${ }_{25}$ A.A. Parker, "The Devil in the Drama of Calderón", en B.W. Wardropper, Critical Essays on the Theatre of Calderón, New York, 1965, pp. 19-20.
} 
plays an independent role, as regards the theme he is the projection, as it were, of the processes that go on within Cyprian's mind, imagination and sensibility.

En efecto, Shelley parece sentirse fascinado por las semejanzas entre el Faust y el Cyprian de la obra de Calderón. Satán (aquí traducido por Daemon), por más que su actitud religiosa le hacía descreer de él como personaje independiente del hombre, era una figura de dimensiones heroicas que tenía fascinado a Shelley, como lo tenía, de igual modo, el Polifemo de los Cíclopes o más aún el Prometeo de Esquilo, otro gran demiurgo rebelde al que habia dedicado un gran poema épico, Prometheus Unbound. En estos héroes trágicos veía Shelley un espíritu castigado para siempre por el poder eterno del tirano, como narrara en su larga obra en verso Queen $M a b$.

Shelley deja de lado varios episodios menores de diálogos entre Clarín, Livia, Moscón, Lelio y Floro. También relega, lo que es de lamentar, los diálogos entre los dos personajes centrales en la relación humana, Justina y Cipriano. Así pues, pasa la página a la Segunda Jornada, donde muestra interés por dos monólogos de Cipriano, que se apresura a traducir. En el primero confiesa su esclavitud hacia un nuevo tirano en su mente, la obsesiva imagen de su amada. $Y$ lo hace con juegos de antitesis casi conceptistas:

\section{Cipriano:}

Idólatra me cegué, ambicioso me perdi, porque una hermosura vi, porque una deidad miré; $y$ entre confusos desvelos de un equívoco rigor conozco a quien tengo amor, y no de quien tengo celos.

Traduce Shelley estos versos de forma libre, y en ellos carga el peso de los conceptos no en rápidos procesos verbales, sino en adjetivos descriptivos carentes de dinamismo. Como resultado el poeta inglés nos da un verso más largo en sílabas, más reposado, y cuyo timbre es, en comparación, grave y meditativo:

\section{Cyprian.}

Vain idolatry! - I saw, And gazing, I became blind with error; Weak ambition, which the awe Of her presence bound to terror! 
So beautiful she was-and I, Between my love and jealousy,

Am so convulsed with hope and fear,

Unworthy as it may appear.

El pasaje más importante en la obra de Calderón es, sin lugar a dudas, el lárgo soliloquio (versos 1295 al 1418) en el que el Demonio narra a Cipriano su larga historia, quien lo toma por un extraño viajero en su camino hacia Antioquía que está dotado de poderes mágicos. Tal personaje parece encarnar tanto al héroe miltoniano como al 'judío errante', personajes muy afectos a la psique del romántico Shelley. Al igual que el 'judio errante', el Demonio es una víctima pasiva de un implacable destino, la venganza de su Dios, que le hace errar eternamente por la faz de la tierra. Estos son los versos iniciales:

Yo soy, pues saberlo quieres, un epílogo, un asombro de venturas y desdichas, que unas pierdo y otras lloro.

Tan galán fui por mis partes, por mi lustre tan heroico, tan noble por mi linaje y por mi ingenio tan docto...

Shelley nos ofrece una interpretación del 'espíritu', más que de la letra, del original español:

Since thou desirest, I will then unveil Myself to thee; for in myself I am A world of hapiness and misery; This have I lost, and that I must lament Forever. In my attributes I stood So high and so heroically great, In lineage so supreme, and with a genius Which penetrated with a glance the world Beneath my feet...

No se nos escapa la gravedad y solemnidad del verso inglés, comparado con la ligereza del español, ya que Shelley parece inspirarse, por su sonora y majestuosa cadencia rítmica, en su admirado Paradise Lost de Milton.

El fragmento de la tercera Jornada (Scene III en la Traducción) Shelley escoge de nuevo un significativo soliloquio del Demonio. La tentación no se 
dirige ahora a la voluptuosidad de Cipriano, sino que lanza el ataque al "virgen edificio de Justina". Un coro de "todos" invocado por el maligno representa las fuerzas que habitan en los abismos y repiten: "Amor, amor". Shelley, sin duda alguna, le vendrá a la mente el coro dramático griego y traduce este pasaje. En el fragmento del verso 2180 leemos el conjuro de seducción de Justina:

Nada miren sus ojos

que no sean de amor dulces despojos;

Nada oigan sus oidos

que no sean de amor tiernos gemidos;

porque, sin que defensa en su fe tenga,

de su ciencia invocada

hoy a buscar a Ciprïano venga,

y de mi ciego espíritu guiada.

La traducción, como siempre, es libre y (re)creativa, aunque esta vez la versión suena más ágil, viva y nerviosa y hace rimar el verso en pareados, a imitación del verso español:

Let nothing meet her eyes

But signs of Love's soft victories;

Let nothing meet her ear

But sounds of Love's sweet sorrow,

So that from faith no succour she may borrow,

But, guided by my spirit blind

And in a magic snare entwined,

She may now seek Cyprian.

Sigue en la traducción una dialéctica conversación tête a tête entre Daemon y Justina, que invoca al "libre albedrío", necesaria para el sentido del "honor", esta vez en boca de una mujer, - lo que no es frecuente en los autos de Calderón-y que es verdadero leitmotiv que recorre toda la obra como asunto de discusión en el ámbito moral y religioso.

Demonio: venciste, mujer, venciste

Con no dejarte vencer.

Daemon: Woman, thou hast subdued me,

Only by not owing thyself subdued. 


\section{Conclusión}

Tres son los temas importantes en El Mágico Prodigioso, según Webb, que han sido objeto de atención por parte de Shelley, a saber: la función del Demonio, los argumentos de la existencia de Dios, y los efectos, peligros y glorias del amor. Las escenas traducidas por Shelley parecen centrarse precisamente en esos temas, si bien había que añadir otros no menos importantes: el conflicto de la conciencia (tema del libre albedrío) y el del poder del mundo natural. Dada la complejidad del primer tema, y sus consecuencias en la tradición religiosa gnóstica, así como sus derivaciones más complejas en el tema de la curiosidad científica relacionado con el bíblico 'árbol del conocimiento' -asuntos todos subyacentes y a veces explícitos en el Faust-, tan sólo haremos una breve alusión final al segundo.

En la Nota 24 señalamos ya la más que probable influencia de las leyendas de magos y nigromantes, como la de Gil de Santarém, en la obra calderoniana. La violencia de la naturaleza recreada por Calderón está en consonancia con la vida emocional (la affective fallacy de la crítica): tempestades, terremotos, vientos, volcanes. Shelley traduce esos pasajes en la segunda Jornada ${ }^{26}$. Arriba también apuntamos la importancia que Shelley daba a los fenómenos atmosféricos como el viento, el agua y los volcanes en su obra. ${ }^{27}$

En la obra es, además, fundamental el ambiente de ilusión, de magia, y de halucinación en que se desenvuelve el amor tempestuoso de los protagonistas. El estado inducido de enamoramiento es algo que se explica por la acción extraordinaria de la magia y la brujería, como ocurriera en La Celestina. La Inquisición estaba atenta a estas manifestaciones nigromantes y hacía mucho por crear una psicosis de delación de prácticas arriesgadas y dudosas con filtros, hierbas y otros ungüentos capaces de variar el estado emocional de la gente. En el Faust también esta práctica de la medicina natural era importante, puesto que los antecedentes reales del personaje pertenecen a una leyenda muy fecunda de astrólogos, médicos, quiromantes, nigromantes y otros practicantes de ciencias denominadas 'ocultas', cuyos saberes se escapaban al vulgo y a los 'jueces' religiosos que a menudo les acusaban de trato íntimo con el diablo. Sin duda un prototipo fue el renacentista Marlowe, autor del Dr Faustus, quien, en cierta forma, se nos asemeja al Shelley romántico.

El crítico Jan Kott destaca al hablar de Marlowe ciertos rasgos que parece repetirse en el héroe byroniano que fue el poeta Shelley:

\footnotetext{
${ }^{26}$ Shelley incluso exageraba en la traducción lo agreste y salvaje del lugar calderoniano: Asi, el "bellísimo laberinto de árboles, flores y plantas" se convierte en "This intricate widerness of trees and flowers and undergrowth of odorous plants". La palabra "wilderness" es, por su frecuencia de uso, una de las preferidas de Shelley.

${ }_{27}$ Cf. sobre todo su gran poema "Ode to the West Wind" como ente personificado y de poder sobrenatural.
} 
It is known, for example, that -even as a university student -he spent some time in France as a secret agent. Moreover, his obstinate defiance of established patterns of thought and behaviour led to charges of atheism, blasphemy and homosexuality being prepared against him by his political oponents. 